\title{
IZAZOVI PRAVNOG UREĐENJA UPOTREBE OSOBNIH PODATAKA IZ GENSKIH TESTOVA U SVRHU OSIGURANJA***
}

Sažetak: $\quad U$ radu se obrađuje problem korištenja genskih testova u svrhu osiguranja. Nakon uvodnog izlaganja u radu se prikazuju razni međunarodni i europski pravni izvori koji se odnose na zaštitu osobnih podataka općenito, pa tako i onih iz genskih testova. Potom se opisuju različita rješenja u poredbenom pravu glede korištenja podataka iz genskih testova u svrhu osiguranja. Ujednima je naglašena apsolutna zabrana korištenja genskih testova u svrhu osiguranja (Francuska, Austrija, Portugal, Hrvatska), a u drugima liberalniji pristup pod određenim pretpostavkama dopušta njihovo korištenje (SAD, Velika Britanija, Njemačka). Zaključuje se kako se zaštitom osobnih podataka ne uklanja apsolutno mogućnost korištenja podataka iz genskih testova u svrhu osiguranja. Ujedno se nameće $i$ potreba jedinstvenog pristupa u regulaciji navedenog pitanja u Europskoj uniji.

Ključne riječi: $\quad$ osiguranje, genski test, osobni podatak, poredbeno pravo, Europska unija, Opća uredba o zaštiti podataka

\section{UVOD}

Ubrzani razvoj genetike i tehnologije omogućio je veliku raširenost genskih testiranja i njihovu sve veću primjenjivost u raznim područjima ljudskog djelovanja i u različite svrhe. Istodobno je povećana i njihova dostupnost, čak i izvan zdravstvenog sustava. ${ }^{1}$ Uobičajeno se

* Dr. sc. Maja Bukovac Puvača, redovita profesorica Pravnog fakulteta Sveučilišta u Rijeci, Hahlić 6, 51000 Rijeka. E-adresa: bukovac@pravri.hr. ORCID: https://orcid.org/0000-0003-3266-2108.

** Dr. sc. Loris Belanić, izvanredni profesor Pravnog fakulteta Sveučilišta u Rijeci, Hahlić 6, 51000 Rijeka. E-adresa: lorisb@pravri. hr. ORCID: https://orcid.org/0000-0002-8275-488X.

*** Ovaj je rad izrađen uz potporu projekta Sveučilišta u Rijeci "Pravni aspekti restrukturiranja trgovačkih društava i tranzicija prema novoj kulturi korporativnog upravljanja” (uniridrustv-18-43).

1 Rastući broj privatnih tvrtki koje nude različite vrste genskih testiranja direktno korisnicima (bez sudjelovanja medicinskih ustanova) pokrenulo je razmišljanja o rizicima koji se uz takvu vrstu usluge javljaju (prvenstveno upitne kvalitete takvih testiranja u koja nisu nužno uključeni medicinski djelatnici ili su uključeni samo formalno, izostanka stručnog genskog savjetovanja prije i nakon testiranja, testiranja maloljetnika itd.) i nužnosti njihove posebne pravne regulacije. Vidi: Pascal Borry and others, 'Legislation on Direct-to-consumer Genetic Testing in Seven European Countries' (2012) 20 European Journal of 
kao cilj uređenja zaštite genskih podataka ističe postizanje ravnoteže između interesa društva (javnog interesa) za rezultatima istraživanja iz područja genetike s jedne i zaštite pojedinca, obitelji odnosno šire zajednice koja je nositelj genskih obilježja, s druge strane. Sam pojam genskog testa kada se koristi u dokumentima različitih pravnih područja (radnom pravu, osiguranju, forenzici, zaštiti osobnih podataka, obiteljskom pravu itd.) različito se definira, a vrlo često ti dokumenti i ne sadrže njegovu definiciju. ${ }^{2}$ Svrha pravne regulacije genskih testova uređivanje je njihova korištenja za identifikaciju osoba, korištenja za medicinsku zaštitu i medicinska istraživanja te zaštita njima dobivenih podataka. Kad bi se ti podaci mogli bez ikakve kontrole i ograničenja otkrivati i koristiti, pojedinci bi zbog njihovih rezultata mogli trpjeti različite povrede svojih prava ili biti prisiljeni podvrgavati se genskom testiranju u različite svrhe, npr. u svrhu zapošljavanja ili osiguranja.

Pitanje korištenja genskih testova u svrhu osiguranja postavlja se u okviru obveza ugovaratelja osiguranja (osiguranika) glede prijave okolnosti značajnih za ocjenu rizika. ${ }^{3}$ Svrha ovakve obveze je na temelju saznanja o okolnostima rizika i njegovim svojstvima, omogućiti osiguratelju donošenje odluka o sklapanju ugovora s ugovarateljem osiguranja i visini premije te odluka o raskidu ugovora, odnosno povećanju premije ako ugovaratelj osiguranja povrijedi obvezu prijave značajnih okolnosti. ${ }^{4}$ Podaci iz genskih testova svakako predstavljaju takve "značajne" okolnosti koje mogu utjecati na odluku osiguratelja o sklapanju ugovora o osiguranju. U skladu s navedenim, postavlja se pitanje odnosi li se prijava značajnih okolnosti i na rezultate iz genskih testova.

Podaci iz genskih testova predstavljaju posebnu kategoriju okolnosti za ocjenu rizika. Naime, pojedinac ne može biti odgovoran za svoje gene, ali osiguratelji, koristeći moderne tehnologije usmjerene na predvidljivost pojave genski uvjetovane bolesti imaju mogućnost prilagodbe premije osiguranja ovisno o "genskoj rizičnosti" pojedinca, ili čak "prerizične" pojedince isključiti iz pokrića rizika. ${ }^{5}$ Opravdano se postavlja pitanje pravednosti takvog postupanja ${ }^{6} \mathrm{~s}$ obzirom na to da tzv. genski rizik predstavlja faktor izvan osiguranikove kontrole. ${ }^{7}$ No činje-

Human Genetics 715-21; Rei Fukuda and Fumio Takada, 'Legal regulations on health-related direct-to-consumer genetic testing in 11 countries' (2018) 48 Kitasato Medical Journal 52-59.

2 Vidi: Orsolova Varga and others, 'Definitions of Genetic Testing in European Legal Documents' (2012) 3 Journal of Community Genetics 125-41.

3 U hrvatskom pravu, pri ugovaranju osigurateljskog pokrića, ugovaratelj osiguranja (osiguranik) ima prema osiguratelju obvezu prijavljivanja svih okolnosti značajnih za ocjenu rizika (čl. 931. Zakona o obveznim odnosima, (NN 35/2005, 41/2008, 125/2011, 78/2015, 29/2018) (HR), dalje: ZOO). Također, i za vrijeme trajanja ugovora o osiguranju postoji obveza prijave promjene okolnosti koje imaju za posljedicu povećanje rizika (čl. 938 ZOO-a). Navedena obveza svojstvena je i za poredbenopravna uređenja. Kao primjer upućujemo na par. 19. st. 1. njemačkog Zakona o ugovoru o osiguranju (Gesetz über den Verisherungsvertrag (Versicherungsvertragsgesetz - VVG) vom 23 November 2007 (BGBl I S. 2631), das zuletzt durch Artikel 2 des Gesetzes vom 10 Juli 2020 (BGBl I S. 1653) geändert worden ist (DE); dalje: VVG); te čl. L. 113-2 t. 2. francuskog Zakonika o osiguranju (Code des assurances (FR) <http://www.legifrance.gouv.fr/affichCode.do?cidTexte=LEGITEXT000006073984〉 pristupljeno 26. siječnja 2021.)

4 Marijan Ćurković, Ugovor o osiguranju - Komentar odredaba Zakona o obveznim odnosima (Inženjerski biro 2017) 71-72; Ana Keglević, Ugovorno pravo osiguranja (Školska knjiga 2016) 346; Drago Pavić, Ugovorno pravo osiguranja (Tectus 2009$) 199$.

5 Nada Bodiroga-Vukobrat and Hana Horak, 'Challenges of Personalized Medicine: Socio-Legal Disputes and Possible Solutions' in Nada Bodiroga-Vukobrat and others (eds), Personalized Medicine: A New Medical and Social Challenge (Springer 2016) 41-42.

6 Ćurković (n 4) 79-80.

7 No, također i spol je kao faktor rizika izvan kontrole osiguranika te prema aktuarskim zakonitostima predstavlja razlog za različito određivanje premija osiguranja između osiguranika muškog i ženskog spola (diskriminacija utemeljena na biološkim obilježjima). Međutim, nakon poznate i povijesne odluke Suda Europske unije u predmetu Test-Achats (Case C-236/09 Association belge des Consommateurs Test-Achats ASBL, Yann van Vugt, Charles Basselier v Conseil des ministres [1 March 2011] ECLI:EU:C:2011:100), spol 
nica jest da su tzv. genske tehnologije svakim danom razvijenije, preciznije i dostupnije te se nužno nameće potreba pravnog uređenja njihove upotrebe i u pogledu osiguranja. Pri tome postoje različiti modaliteti uređenja koji se kreću od apsolutne zabrane do određene dopustivosti korištenja genskih tehnologija u svrhu osiguranja, a koji se u radu namjeravaju istražiti.

\section{PODACI IZ GENSKIH TESTOVA KAO OSOBNI PODACI I NJIHOVA ZAŠTITA U MEĐUNARODNIM I EUROPSKIM PRAVNIM IZVORIMA}

\subsection{MEĐUNARODNI INSTRUMENTI}

Pravo svake osobe na zaštitu privatnosti proklamirano Općom deklaracijom o ljudskim pravi$\mathrm{ma}^{8}$ dobilo je svoju potvrdu u Konvenciji za zaštitu ljudskih prava i temeljnih sloboda ${ }^{9}$ koju je 1950. godine usvojilo Vijeće Europe. Ovom se Konvencijom izričito ne jamči pravo na zaštitu osobnih podataka, ali se to pravo smatra nužnim za ostvarivanje prava na zaštitu privatnog i obiteljskog života. Obuhvaća li koncept privatnog i obiteljskog života iz čl. 8. EKLJP-a i podatke iz genskih testova i pod kojim pretpostavkama Europski sud za ljudska prava još nije razmatrao, ali u prilog takvog shvaćanja mogu se navesti odluke o srodnim pitanjima, vezanim za genetski materijal. ${ }^{10}$

Vijeće Europe usvojilo je 1997. godine i prvi međunarodni pravno obvezujući instrument iz područja biomedicine, Konvenciju o ljudskim pravima i biomedicini (tzv. Oviedo Konvencija). ${ }^{11}$ Njome je izričito zabranjena diskriminacija koja bi se temeljila na genskom nasljeđu (čl. 11. KLJPB-a), a ograničena je i uporaba pretkazujućih genskih testova na način da se oni mogu obavljati samo u zdravstvene svrhe ili radi zdravstvenog istraživanja vezanog uz te svrhe i uz odgovarajuće genetsko savjetovanje (čl. 12. KLJPB-a). Dodatni protokol uz ovu Konvenciju iz

više ne smije biti faktor za izračun individualnih premija i koristi iz osiguranja. Ima razmišljanja kako presuda Test Achats ima puno dublje značenje te osim zabrane spolne diskriminacije u osiguranju, može poslužiti i kao osnova zabranu diskriminacije na temelju genskog nasljeđa s obzirom na to da na gene, kao ni na spol, osiguranik ne može utjecati. Ipak, za takvo što bila bi potrebna konkretna regulativa na razini EU-a, a spomenuta presuda može predstavljati određeni “okidač" u tom pravcu. James Davey, 'Genetic Discrimitantion in Insurance: Lessons from Test Achats' in Gerard Quinn, Aisling de Paor and Peter Blanck (eds), Genetic Discrimination, Transatlantic Perpectives on the Case for European Legal Response (Routledge 2015) 149-50, 158-59.

8 Opća deklaracija o ljudskim pravima (usvojena i proglašena Rezolucijom Opće skupštine Ujedinjenih naroda 217A/III, 10. prosinca 1948.); Odluka o objavi Opće deklaracije o ljudskim pravima (NN-MU 12/2009) (HR)

"Nitko ne smije biti podvrgnut samovoljnom miješanju u njegov privatni život, obitelj, dom ili dopisivanje, niti napadima na njegovu čast i ugled. Svatko ima pravo na zakonsku zaštitu protiv takvog miješanja ili napada." (čl. 12.).

9 Zakon o potvrđivanju Konvencije za zaštitu ljudskih prava i temeljnih sloboda i Protokola br. 1., 4., 6., 7., i 11. uz Konvenciju za zaštitu ljudskih prava i temeljnih sloboda (NN-MU 18/1997) (HR) (dalje: EKLJP).

čl. 8.: "1. Svatko ima pravo na poštovanje svoga privatnog i obiteljskog života, doma i dopisivanja.

2. Javna vlast se neće miješati u ostvarivanje tog prava, osim u skladu sa zakonom i ako je u demokratskom društvu nužno radi interesa državne sigurnosti, javnog reda i mira, ili gospodarske dobrobiti zemlje, te radi sprečavanja nereda ili zločina, radi zaštite zdravlja ili morala ili radi zaštite prava i sloboda drugih." bića u pogledu primjene biologije i medicine o zabrani kloniranja ljudskih bića i Dodatnog protokola uz Konvenciju o zaštiti ljudskih prava i dostojanstva ljudskog bića u pogledu primjene biologije i medicine, u vezi presađivanja organa i tkiva ljudskog porijekla (NN-MU 13/2003) (HR) (dalje: KLJPB). Republika Hrvatska je ratificirala samo prva dva protokola uz ovu Konvenciju (Protokol br. 1 o zabrani kloniranja iz 1998. i Protokol br. 2 o transplantaciji organa iz 2002.). Protokol br. 3 o biomedicinskim istraživanjima iz 2005. i Protokol br. 4. o genskom testiranju iz 2008. nisu potpisani. 
2008. godine koji se odnosi na genska testiranja u medicinske svrhe ${ }^{12}$ propisuje, među ostalim, da se genska testiranja mogu obavljati samo uz individualni medicinski nadzor (čl. 7. st. 1. Protokola br. 4), uz prethodni slobodno dan informirani pristanak koji se može opozvati u svako doba (čl. 9. st. 1. i 2. Protokola br. 4), te da svatko ima pravo na poštovanje svog privatnog života i posebno zaštitu podataka dobivenih iz genskih testova (čl. 16. st. 1. Protokola br. 4). ${ }^{13}$ Zasad je relativno mali broj država potpisao i ratificirao ovaj Protokol. ${ }^{14}$

Od velikog broja pravno neobvezujućih akata Vijeća Europe za temu ovoga rada najbitnija je Preporuka o obradi zdravstvenih podataka, uključujući i podatke iz genskih testova u svrhu osiguranja, koju je Odbor ministara donio 2016. godine. ${ }^{15}$ Načelo broj 4 ove Preporuke zabranjuje osigurateljima da zahtijevaju genske testove u svrhu osiguranja. ${ }^{16}$ Pozivajući se na članak 12. Konvencije o ljudskim pravima i biomedicini, preporuka zabranjuje korištenje prediktivnih genskih testova u osigurateljske svrhe (čl. 15. Preporuke). Postojeći podaci iz prediktivnih genskih testova ne smiju se obrađivati u svrhu osiguranja, osim ako to nije posebno zakonom propisano (čl. 16. Preporuke), dok se postojeći rezultati genskih testova članova obitelji osiguranika uopće ne mogu koristiti u svrhu osiguranja (čl. 17. Preporuke).

Veliki doprinos razvoju međunarodnih standarda u biomedicini dao je i UNESCO svojim deklaracijama: Općom deklaracijom o bioetici i ljudskim pravima, ${ }^{17}$ Međunarodnom deklaracijom o ljudskim genetičkim podacima ${ }^{18}$ i Općom deklaracijom o ljudskom genomu i ljudskim pravima. ${ }^{19,20}$ Iako su prema svojoj pravnoj prirodi neobvezujuće, one predstavljaju jasne smjernice nacionalnim zakonodavcima za pravno reguliranje ovog, za ljudska prava posebno rizičnog područja medicine.

12 Council of Europe, Additional Protocol to the Convention on Human Rights and Biomedicine, concerning Genetic Testing for Health (Council of Europe Treaty Series No 203, 2008) <https://rm.coe.int/1680084824> pristupljeno 26. siječnja 2021. (dalje: Protokol br. 4).

13 Članak 16. st. 2.: "Everyone undergoing a genetic test is entitled to know any information collected about his or her health derived from this test. The conclusions drawn from the test shall be accessible to the person concerned in a comprehensible form."

Stavak 3: "The wish of a person not to be informed shall be respected."

Stavak 4: "In exceptional cases, restrictions may be placed by law on the exercise of the rights contained in paragraphs 2 and 3 above in the interests of the person concerned."

14 Do 27. siječnja 2021. godine potpisale i ratificirale su ga Češka, Crna Gora, Norveška, Portugal, Moldavija i Slovenija, a samo potpisale Finska, Francuska, Island i Luxembourg. Stanje ratifikacija i potpisa vidi na: Chart of signatures and ratifications of Treaty 203 (Additional Protocol to the Convention on Human Rights and Biomedicine concerning Genetic Testing for Health Purposes) <https://www.coe.int/en/web/conventions/full-list/-/conventions/treaty/203/signatures?p_auth=rLWABa1h> pristupljeno 26. siječnja 2021.

15 Recommendation CM/Rec(2016)8 of the Committee of Ministers to the member States on the processing of personal healthrelated data for insurance purposes, including data resulting from genetic tests (Adopted by the Committee of Ministers on 26 October 2016 at the 1269th meeting of the Ministers' Deputies) <https://search.coe.int/cm/Pages/result_details. aspx?ObjectID=09000016806b2c5f > pristupljeno 26. siječnja 2021. (dalje: Preporuka).

16 "Principle 4 - Insurers should not require genetic tests for insurance purposes."

17 Universal Declaration on Bioethics and Human Rights (adopted by UNESCO's General Conference on 19 October 2005) <https:// en.unesco.org/themes/ethics-science-and-technology/bioethics-and-human-rights> pristupljeno 26. siječnja 2021.

18 International Declaration on Human Genetic Data (16 October 2003) <https://en.unesco.org/themes/ethics-science-andtechnology/human-genetic-data> pristupljeno 20. siječnja 2021.

19 Universal Declaration on the Human Genome and Human Rights (UNESCO, 11 November 1997) <https://en.unesco.org/ themes/ethics-science-and-technology/human-genome-and-human-rights> pristupljeno 26. siječnja 2021.

20 Prijevodi svih triju deklaracija na hrvatski jezik sadrži: Judit Sándor (ed), UNESCO i bioetika: zbirka osnovnih dokumenata (Center for Ethics and Law in Biomedicine 2008). 


\subsection{PRAVO EUROPSKE UNIJE}

Budući da članice EU-a ne dijele isti međunarodnopravni okvir postavljen Konvencijom o ljudskim pravima i biomedicini i njezinim dodatnim protokolima, ${ }^{21}$ i na razini EU-a otvorilo se pitanje načina i opsega zaštite podataka iz genskih testova. U dosad provedenim istraživanjima nacionalnih regulatornih okvira zaključeno je da su u vezi s pitanjem takve zaštite $u$ nacionalnim pravima država članica prisutna vrlo različita rješenja. ${ }^{22}$ U primarnim se izvorima europskog prava nalaze temelji njezina nastanka i funkcioniranja, kao i garancije temeljnih ljudskih prava njezinih građana. Ugovor o funkcioniranju Europske unije $\mathrm{e}^{23} \mathrm{u}$ čl. 2. propisuje da se ona temelji na "vrijednostima poštovanja ljudskog dostojanstva, slobode, demokracije, jednakosti, vladavine prava i poštovanja ljudskih prava, uključujući i prava pripadnika manjina”, a u čl. 3. st. 3. da ona "(...) suzbija društvenu isključenost i diskriminaciju, promiče socijalnu pravdu i zaštitu, ravnopravnost žena i muškaraca, međugeneracijsku solidarnost i zaštitu prava djeteta." U Povelji Europske unije o temeljnim pravima ${ }^{24}$ pravo na poštovanje privatnog i obiteljskog života i pravo na zaštitu osobnih podataka regulirani su različitim člancima (čl. 7 . i 8. Povelje). ${ }^{25}$ Člankom 21. Povelje izričito je zabranjena diskriminacija koja bi se temeljila na genetskim osobinama čovjeka. ${ }^{26}$

\subsubsection{Opća uredba o zaštiti podataka}

\subsubsection{Definicija genskog podatka}

Uredba (EU) 2016/679 Europskog parlamenta i Vijeća od 27. travnja 2016. o zaštiti pojedinaca u vezi s obradom osobnih podataka i o slobodnom kretanju takvih podataka te stavljanju izvan snage Direktive 95/46/EZ (Opća uredba o zaštiti podataka) ${ }^{27}$ u cijelosti je obvezujuća i od 25. svibnja 2018. godine izravno se primjenjuje u svim državama članicama Europske unije. Države članice tako su dobile zajedničko uređenje zaštite osobnih podataka, a u okviru njega i

21 Nisu sve države članice potpisale i ratificirale Konvenciju, a one koje jesu nisu na jednak način potpisivale i ratificirale njezine protokole.

22 Vidi u kasnijim točkama rada, infra 3.2, 3.3. i 4

23 Ugovor o funkcioniranju Europske unije (pročišćena verzija) [2016] SL C202/47

24 Povelja Europske unije o temeljnim pravima (2016/C 202/02) [2016] SL C202/389, 389-405.

25 Članak 7. Poštovanje privatnog i obiteljskog života: "Svatko ima pravo na poštovanje svojeg privatnog i obiteljskog života, doma i komuniciranja." Članak 8. Zaštita osobnih podataka: "Svatko ima pravo na zaštitu osobnih podataka koji se na njega ili nju odnose. 2. Takvi podaci moraju se obrađivati pošteno, u utvrđene svrhe i na temelju suglasnosti osobe o kojoj je riječ, ili na nekoj drugoj legitimnoj osnovi utvrđenoj zakonom. Svatko ima pravo na pristup prikupljenim podacima koji se na njega ili nju odnose i pravo na njihovo ispravljanje."

Iako je pravo na zaštitu osobnih podataka u Povelji potpuno odvojeno i neovisno o drugim temeljnim pravima, ono nije apsolutno i potrebno ga je, u skladu s njegovom društvenom ulogom i načelom proporcionalnosti, promatrati u odnosu s drugim temeljnim pravima (vidi Recital 4. Uredbe).

26 Članak 21. Nediskriminacija.

1. “Zabranjuje se svaka diskriminacija na bilo kojoj osnovi kao što je spol, rasa, boja kože, etničko ili socijalno podrijetlo, genetske osobine, jezik, religija ili uvjerenje, političko ili bilo kakvo drugo mišljenje, pripadnost nacionalnoj manjini, imovina, rođenje, invaliditet, dob ili spolna orijentacija."

27 [2016] SL L119/1 (dalje u tekstu: Uredba); Ispravak Uredbe (EU) 2016/679 Europskog parlamenta i Vijeća od 27. travnja 2016. o zaštiti pojedinaca u vezi s obradom osobnih podataka i o slobodnom kretanju takvih podataka te o stavljanju izvan snage Direktive 95/46/EZ (Opća uredba o zaštiti podataka) [2018] SL L127/2. 
podataka iz genskih testova. Potrebno je naglasiti da u dosadašnjem uređenju zaštite podataka na razini EU-a (Direktivi 95/46/EZ) genski podaci nisu bili izričito predviđeni kao posebna kategorija osobnih podataka.

Osobni su podaci za potrebe Uredbe definirani kao svi podaci koji se odnose na pojedinca čiji je identitet utvrđen ili se može utvrditi, izravno ili neizravno. Identitet pojedinca može se utvrditi osobito uz pomoć identifikatora kao što su ime, identifikacijski broj, podaci o lokaciji, mrežni identifikator ili uz pomoć jednog ili više čimbenika svojstvenih za fizički, fiziološki, genetski, mentalni, ekonomski, kulturni ili socijalni identitet tog pojedinca (čl. 4. t. 1. Uredbe).

Članak 4. t. 13. Uredbe: "genetski podaci” znači osobni podaci koji se odnose na naslijeđena ili stečena genetska obilježja pojedinca koja daju jedinstvenu informaciju o fiziologiji ili zdravlju tog pojedinca, i koji su dobiveni osobito analizom biološkog uzorka dotičnog pojedinca. Prema Recitalu 34. Uredbe: "Genetski podaci trebali bi se definirati kao osobni podaci u vezi s naslijeđenim ili stečenim genetskim obilježjima pojedinca koji proizlaze iz analize biološkog uzorka pojedinca o kojemu je riječ, osobito analize kromosoma, deoksiribonukleinske kiseline (DNK) ili ribonukleinske kiseline (RNK) ili iz analize drugog elementa koji omogućuje dobivanje jednakovrijedne informacije." Osobni podaci koji se odnose na zdravlje, uključuju, među ostalim, i "informacije izvedene iz testiranja ili ispitivanja dijela tijela ili tjelesne tvari, među ostalim iz genetskih podataka i bioloških uzoraka” (vidi Recital 35. Uredbe).

\subsubsection{Subjekti zaštite}

Uredba se primjenjuje na obradu ${ }^{28}$ osobnih podataka pojedinaca (fizičkih osoba), ${ }^{29}$ bez obzira na to obavlja li se automatizirano ili neautomatizirano, ako ti podaci čine dio sustava pohrane ili su za to namijenjeni. ${ }^{30}$ Uredba štiti podatke samo živih osoba i državama članicama prepušta reguliranje obrade podataka umrlih osoba (Recital 27. Uredbe).

Genski podaci, prema svojoj prirodi, odnose se i na žive i na umrle osobe. Budući da Uredba štiti samo podatke živih osoba i za osobne podatke umrlih osoba ostavlja državama članicama uređivanje pitanja njihove obrade, ${ }^{31}$ pitanje zaštite genskih podataka umrlih osoba regulirano je na nacionalnoj razini. Mogućnost da zbog nezakonite obrade genskih podataka umrle osobe dođe do povrede prava živih osoba svakako nije zanemariva. Specifičnost podataka iz genskih testova upravo je u tome da se sadržaj koji pružaju (genske informacije), ne odnose samo na jedan subjekt obrade, već na sve subjekte koji dijele isto genetsko naslijeđe. Svoju "gensku osobnost" pojedinac dijeli s određenim krugom srodnika i pripadnika šire grupacije i problem zaštite tih podataka nužno nije ograničen na zaštitu osobe od koje neposredno potječe genski materijal.

28 Obrada se definira kao "svaki postupak ili skup postupaka koji se obavljaju na osobnim podacima ili na skupovima osobnih podataka, bilo automatiziranim bilo neautomatiziranim sredstvima kao što su prikupljanje, bilježenje, organizacija, strukturiranje, pohrana, prilagodba ili izmjena, pronalaženje, obavljanje uvida, uporaba, otkrivanje prijenosom, širenjem ili stavljanjem na raspolaganje na drugi način, usklađivanje ili kombiniranje, ograničavanje, brisanje ili uništavanje" (čl. 4. t. 2. Uredbe).

29 Članak 1. st. 1. Uredbe. Recital 14. naglašava da se zaštita pruža isključivo fizičkim osobama, bez obzira na njihovo državljanstvo ili boravište. Izričito isključuje mogućnost da se njome obuhvate osobni podaci koji se tiču pravnih osoba, osobito poduzetnika. 


\subsubsection{Načelna zabrana obrade genskih podataka i izuzeci od te zabrane}

Zbog svoje sposobnosti da omoguće donošenje zaključaka o pojedincima povezanih s njihovim temeljnim pravima i slobodama i njihova obrada predstavlja visok rizik za ta prava i slobode, genski su podaci Uredbom kvalificirani kao posebna kategorija osobnih podataka, čija je obrada samo izuzetno dopuštena. Naime, u čl. 9. st. 1. Uredbe propisana je zabrana obrade takve vrste podataka, ${ }^{32}$ dok su u idućem stavku propisani slučajevi kada se ta zabrana ne primjenjuje (čl. 9. st. 2. t. a - j Uredbe).

Izričiti pristanak ispitanika može ukinuti zabranu obrade takvih podataka, osim ako pravom Unije ili države članice nije propisano da ispitanik tu zabranu ne može ukinuti. ${ }^{33}$ Zabranu obrade takvih podataka ukida i nužnost njihove obrade za zaštitu životno važnih interesa ispitanika ili druge osobe ako ispitanik nije u mogućnosti dati pristanak (čl. 9. st. 2. t. c Uredbe), nužnost obrade u nizu slučajeva u kojima se obrada vrši u javnom interesu, ${ }^{34} u$ području radnog i socijalnog prava i socijalne zaštite, ${ }^{35} \mathrm{u}$ svrhu ostvarivanja pravnih zahtjeva i djelovanja sudova, ${ }^{36} \mathrm{u}$ sklopu legitimnih aktivnosti neprofitnih tijela, ako se odnosi na njihove članove. ${ }^{37}$ Zabrana se ne odnosi na podatke za koje je očito da ih je sam ispitanik objavio. ${ }^{38}$ U slučaju da je obrada nužna u svrhu preventivne medicine ili medicine rada radi procjene radne sposobnosti zaposlenika, medicinske dijagnoze, pružanja zdravstvene ili socijalne skrbi ili tretmana ili upravljanja zdravstvenim ili socijalnim sustavima i uslugama na temelju prava Unije ili prava države članice ili u skladu s ugovorom sa zdravstvenim radnikom (čl. 9. st. 2. t. h Uredbe), zabrana neće vrijediti samo ako podatke obrađuje stručno tijelo ili se oni obrađuju pod njegovom odgovornošću (čl. 9. st. 3. Uredbe). Države članice mogu zadržati ili uvesti dodatne uvjete, uključujući ograničenja s obzirom na obradu genetskih podataka, biometrijskih podataka ili podataka koji se odnose na zdravlje (čl. 9. st. 4. Uredbe).$^{39}$

Specifičnost zaštite koju Uredba pruža posebnim kategorijama osobnih podataka jest u tome da je njihova obrada načelno zabranjena, ali je pod određenim pretpostavkama i u određene svrhe dopuštena. Upravo se genski podaci, biometrijski podaci i podaci koji se odnose na zdravlje, izdvajaju kao potkategorije posebnih podataka za koje se državama članicama dopušta da uvedu i dodatne uvjete i ograničenja njihove obrade, dakle još više ograniče njihovu obradu i dodatno zaštite ispitanike.

32 Članak 9. st. 1. Zabranjuje se obrada osobnih podataka koji otkrivaju rasno ili etničko podrijetlo, politička mišljenja, vjerska ili filozofska uvjerenja ili članstvo u sindikatu te obrada genetskih podataka, biometrijskih podataka u svrhu jedinstvene identifikacije pojedinca, podataka koji se odnose na zdravlje ili podataka o spolnom životu ili seksualnoj orijentaciji pojedinca.

Tako je npr. u Hrvatskoj člankom 20. Zakona o provedbi Opće uredbe o zaštiti osobnih podataka (NN 42/2018) (HR) izričito propisano da se pristankom ispitanika ne može ukloniti zabrana obrade genskih podataka u svrhu osiguranja (vidi: infra 4).

Npr. značajni javni interes na temelju prava Unije ili države članice, javni interes u području javnog zdravlja, javni interes u svrhe znanstvenog ili povijesnog istraživanja ili u statističke svrhe (čl. 9. st. 2. t. g, i, j Uredbe).

Članak 9. st. 2. t. b. Uredbe.

36 Članak 9. st. 2. t. f. Uredbe.

37 Članak 9. st. 2. t. d. Uredbe.

38 Članak 9. st. 2. t. e. Uredbe.

39 Recital 53. Uredbe. “(...)Državama članicama trebalo bi omogućiti zadržavanje ili uvođenje dodatnih uvjeta, uključujući ograničenja, u vezi s obradom genetskih podataka, biometrijskih podataka ili podataka koji se odnose na zdravlje. Međutim, to ne bi trebalo spriječiti slobodan protok osobnih podataka unutar Unije ako se ti uvjeti primjenjuju na prekograničnu obradu takvih podataka." 
U onim slučajevima kada je obrada genskih podataka dopuštena, ona je podvrgnuta općim načelima obrade osobnih podataka. ${ }^{40}$ Povrede prava na zaštitu osobnih podataka mogu proizlaziti iz povrede načela obrade podataka, ${ }^{41}$ povrede prava ispitanika ${ }^{42}$ i povreda pojedinih obveza voditelja i izvršitelja obrade. ${ }^{43} \mathrm{U}$ svrhu osiguranja poštene i transparentne obrade podataka, voditelj mora koristiti odgovarajuće postupke koji će pogreške i netočnosti svesti na minimum i posebne kategorije osobnih podataka osigurati od potencijalnih rizika za prava i interese ispitanika i spriječiti njihovu diskriminaciju. Samo izuzetno smije se dopustiti izrada profila i automatizirane odluke na temelju tih posebnih kategorija podataka (vidi Recital 71. Uredbe).

S obzirom na opću definiciju povrede osobnih podataka iz čl. 4. t. 12. Uredbe, ${ }^{44}$ povredu podataka iz genskih testova predstavljalo bi kršenje sigurnosti koje je dovelo do slučajnog ili nezakonitog uništenja, gubitka, izmjene, neovlaštenog otkrivanja ili pristupa genskim podacima koji su preneseni, pohranjeni ili na drugi način obrađivani. U VIII. poglavlju (čl. 77.-84.) Uredba propisuje pravna sredstva, odgovornost i sankcije za slučajeve povreda osobnih podataka, koje, naravno, vrijede i za slučajeve povrede genskih podataka.

\section{POREDBENOPRAVNA ANALIZA MOGUĆNOSTI PRISTUPA PODACIMA IZ GENSKIH TESTOVA}

\subsection{VELIKA BRITANIJA, SAD I AUSTRALIJA}

U Velikoj Britaniji Vlada i Udruženje britanskih osiguratelja (ABI, Association of British Insurers) zajednički su donijeli Kodeks o genskom testiranju i osiguranju (Code on Genetic Testing and Insurance $)^{45} \mathrm{u}$ listopadu 2018. godine. Kodeksom se uređuje mogućnost korištenja genskih testova u svrhu osiguranja, odnosno ima za cilj spriječiti korištenje istih bez ikakvih ograničenja. ${ }^{46}$

40 Općenito o načelima obrade osobnih podataka vidi: Maja Bukovac Puvača and Armando Demark, 'Pravo na zaštitu osobnih podataka kao temeljno pravo i odgovornost za štetu zbog njegove povrede' (2019) 40(1) Zbornik Pravnog fakulteta Sveučilišta u Rijeci 297-98.

41 To su: zakonitost, poštenost i transparentnost njihove obrade, ograničavanje svrhe, smanjenje količine podataka, točnost, ograničenje pohrane, cjelovitost i povjerljivost (vidi čl. 5. st. 1. Uredbe). Za usklađenost obrade s navedenim načelima odgovoran je voditelj obrade i mora biti u mogućnosti dokazati je (čl. 5. st. 1. Uredbe).

42 To su pravo na transparentne informacije i pristup osobnim podacima (čl. 13.-15. Uredbe), pravo na ispravak podataka (čl. 16. Uredbe), pravo na brisanje (čl. 17. Uredbe), pravo na ograničenje obrade (čl. 18. Uredbe), obveza izvješćivanja u vezi s ispravkom ili brisanjem osobnih podataka ili ograničenjem obrade (čl. 19. Uredbe), pravo na prenosivost podataka (čl. 20. Uredbe), pravo na prigovor na obradu (čl. 21. Uredbe) i automatizirano pojedinačno donošenje odluka (čl. 22. Uredbe). Sva se navedena prava mogu zakonom ograničiti, ako se takvim ograničenjem poštuje bit temeljnih prava i sloboda te ono predstavlja nužnu i razmjernu mjeru u demokratskom društvu za zaštitu važnih ciljeva od općeg javnog interesa (čl. 23. st. 1. Uredbe).

43 U odjeljku 1. IV. poglavlja Uredba detaljno propisuje opće obveze voditelja i izvršitelja obrade. One se odnose na provođenje odgovarajućih tehničkih i organizacijskih mjera kojima se treba osigurati sigurnost osobnih podataka, odnosno spriječiti povrede tih podataka. Sama sigurnost obrade predmet je detaljnog uređenja u odjeljku 2. istoga poglavlja.

44 "Povreda osobnih podataka" znači kršenje sigurnosti koje dovodi do slučajnog ili nezakonitog uništenja, gubitka, izmjene, neovlaštenog otkrivanja ili pristupa osobnim podacima koji su preneseni, pohranjeni ili na drugi način obrađivani (čl. 4. t. 12. Uredbe).

45 Code on Genetic Testing and Insurance (UK) <https://www.abi.org.uk/data-and-resources/tools-and-resources/genetics/codeon-genetic-testing-and-insurance> pristupljeno 26. siječnja 2021.

46 Bez takvog Kodeksa britanski osiguratelji imali bi neograničeno pravo koristiti rezultate genskih testova pozivom na opće odredbe iz ugovornog prava osiguranja o obvezi prijavljivanja svih okolnosti relevantnih za ocjenu rizika, a što u slučaju povrede 
Sam Kodeks predstavlja neku vrstu "moralne obveze", odnosno etičkog kodeksa za postupanje osiguratelja u Velikoj Britaniji kada je u pitanju korištenje podataka iz genskih testova u svrhu osiguranja. Povreda odredbi Kodeksa nema za posljedicu zabranu osiguratelju da i dalje obavlja djelatnost osiguranja, no može dovesti do brisanja iz članstva Udruženja, a što negativno utječe na poslovni ugled. ${ }^{4}$

Kodeks se temelji na dva temeljna načela: 1) osiguratelj ne može od potencijalnog (budućeg) osiguranika prije sklapanja ugovora o osiguranju, ali niti od postojećeg osiguranika (tj. osiguranika iz ugovora o osiguranju koji su već sklopljeni i pružaju osigurateljsko pokriće u trenutku donošenja Kodeksa) zahtijevati podvrgavanje genskom testiranju, 2) rezultati prediktivnih genskih testova mogu se uzeti u obzir pri sklapanju ugovora o osiguranju uz kumulativno ispunjavanje dvaju uvjeta: a) da je Kodeksom posebno predviđen genski test čiji se rezultati mogu uzeti u obzir ${ }^{48} \mathrm{i}$ b) da svota osiguranja prelazi iznose koji su predviđeni Kodeksom. ${ }^{49}$ Dodatna ograničenja tiču se vrsta osiguranja u pogledu kojih osiguratelj može uzeti u obzir rezultate genskih testova. U skladu s navedenim, u čl. 2 Kodeksa propisano je da osiguratelji mogu uzeti u obzir rezultate genskih testova (i to samo ako su se osiguranici samostalno odlučili na gensko testiranje, a nipošto na "nagovor" osiguratelja) kod: 1) osiguranja života (life insurance) ako je ugovorena svota viša od 500.000 funti po osobi, 2) osiguranja od teških bolesti (critical illnes insurance) ako je ugovorena svota viša od 300.000 funti po osobi te 3) osiguranja prihoda (income protection insurance) ako je ugovorena svota viša od 30.000 funti na godinu. ${ }^{50}$ Izričito se naglašava kako se prediktivni genski testovi neće tražiti niti uzimati u obzir kod ostalih vrsta osiguranja neovisno o visini svote osiguranja. No, to ne isključuje pravo osiguratelja da bude informiran o zdravstvenom stanju svojeg osiguranika, naravno uz njegov pristanak, na temelju ostalih medicinskih podataka (npr. podaci iz zdravstvenog kartona, medicinskih pretraga - npr. krvi, urina i sl.), uključujući i dijagnostičke genske testove koji se odnose na potvrdu bolesti odnosno zdravstvenog stanja. ${ }^{51}$

U pravu Sjedinjenih Američkih Država na saveznoj razini u primjeni su dva zakona koja uređuju pitanje korištenja podataka iz genskih testova u svrhu osiguranja: 1) Zakon o zabrani diskriminacije na temelju genskih informacija u pogledu zdravstvenog osiguranja i zapošljavanja (The Genetic Information Nondiscrimination Act, skraćeno: GINA) iz 2008 godine ${ }^{52}$ te 2) Zakon o zaštiti pacijenata i pristupačnoj zdravstvenoj skrbi (The Patient Protection and Afford-

takve obveze može imati za posljedicu ništetnost ugovora o osiguranju. Ruth Stirton, Genetic Information and the Future of Industry Self-Regulation in the UK' (2012) 4(2) Law, Innovation and Technology 215.

Ibid 219, 222.

Takvi genski testovi navedeni su u Dodatku I. Kodeksa (Appendix I), a trenutačno je na listi samo genski test za Huntigtonovu bolest i to samo ako se ugovara osiguranje života za iznos iznad 500.000 funti (Kodeks, str. 14).

Kodeks, str. 3.

Tijekom 2018. godine bilo je ukupno ugovoreno ispod propisanih limita (iznad kojih postoji obveza prijave podataka iz obavljenih genskih testova) 95\% polica osiguranja života (limit 500.000 funti), 98\% polica osiguranja od teških bolesti i 94\% polica osiguranja od ubrzanih teških bolesti (limit 300.000 funti) te $91 \%$ polica osiguranja prihoda (limit 30.000 funti). Code on Genetic Testing and Insurance: Annual Report 2019 (The Association of British Insurers 2019) <https://www.abi.org. uk/globalassets/files/publications/public/genetics/abi-2019-annual-report-on-code-on-genetic-testing-and-insurance.pdf > pristupljeno 26. siječnja 2021.

Kodeks, Uvodni dio, str. 4.

The Genetic Information Nondiscrimination Act of 2008, Public Law 110-233, 122 Stat 881 (21 May 2008) (US) 
able Care Act, skraćeno ACA) iz 2010. godine, ${ }^{53}$ poznatiji pod nazivom Obamacare. Oba zakona odnose se na pitanje ograničavanja dostupnosti podataka iz genskih testova osigurateljima zdravstvenog osiguranja, čime se olakšava i pristup zdravstvenoj skrbi s obzirom na činjenicu da su njezini troškovi u SAD-u prvenstveno pokriveni privatnim zdravstvenim osiguranjem, a ne državnim kao što je to slučaj u Europi ${ }^{54}$ GINA se primjenjuje na prediktivne genske testove koji imaju za cilj prognozu eventualne pojave bolesti u budućnosti (dakle, prije simptoma neke bolesti). Navedeni Zakon osigurateljima izričito zabranjuje korištenje genskih informacija pri odlučivanju o sklapanju ugovora o zdravstvenom osiguranju kao i za određivanje visine premije, a ujedno zabranjuje zahtijevati od osiguranika podvrgavanje genskom testiranju kao uvjet za pružanje osigurateljskog pokrića (čl. 101., st. a3., čl. 102., st. a3., čl. 103., a3., čl. 104. st. - aE, čl. 2753. st. a1. i b1., GINA-e). S druge strane, ACA zabranjuje diskriminaciju na temelju tzv. dijagnostičkih genskih testova koji se poduzimaju u svrhu liječenja ili potvrde neke dijagnoze (dakle, kada simptomi bolesti već postoje, pa osiguratelji ne smiju uskratiti pokriće na temelju prethodnog ili postojećeg zdravstvenog stanja). ${ }^{55} \mathrm{U}$ vezi s ostalim osiguranjima osoba, kao što su životna osiguranja i invalidska osiguranja, odnosno osiguranja dugotrajne njege, navedeni se zakoni ne primjenjuju što znači da u tim vrstama osiguranja osiguratelji mogu koristiti genske testove za donošenje odluke o osigurateljskom pokriću, ovisno o zakonodavstvu pojedinih saveznih država. ${ }^{56,57}$

U australskom pravu, mogućnost i pretpostavke osigurateljima da pristupe podacima iz genskih testova uređeno je Moratorijem o genetskim testovima u životnom osiguranju od 21. lipnja 2019. godine (Moratorium on Genetic Tests in Life Insurance), ${ }^{58}$ a primjenjuje se na pet godina (od 1. srpnja 2019. do 30. lipnja 2024. godine, čl. 2.2. Moratorija). Kao i Kodeks o genskom testiranju i osiguranju u pravu Velike Britanije, ni australski Moratorij nije zakonski akt već se on dobrovoljno primjenjuje u poslovnoj praksi australskih osiguratelja. ${ }^{59}$ Navedeni Moratorij odnosi se samo na pokrića glede životnih osiguranja koja su dostupna na tržištu, dok je zdravstveno osiguranje u nadležnosti državnih osiguratelja kod kojih se uopće ne postavlja pitanje prijave podataka iz genskih testova za ugovaranje osigurateljskog pokrića. ${ }^{60}$

Moratorij se temelji na načelu da su, pri ugovaranju životnog osiguranja, neovisno o ugovorenoj svoti osiguranja, osiguratelji ovlašteni postavljati pitanja ugovaratelju osiguranja/osi-

53 The Patient Protection and Affordable Care Act of 2010, Public Law 111-148, 124 Stat 119, (23 March 2010) (US)

54 Aisling de Paor, 'Advancing Science and Controlling the Misuse of Genetic Information in Employment and Insurance: Towards an Effective European Union Regulatory Framework' (PhD thesis, School of Law, National University of Ireland 2013) 167.

55 Andrea Aikin, 'Contradiction in Terms: Genetic Nondiscrimination and Long-Term Care Insurance' (2016) 53(4) University of Louisville Law Review 620.

56 Sarah Zhang, 'The Loopholes in the Law Prohibiting Genetic Discrimination' The Atlantic (13 March 2017) <https://www. theatlantic.com/health/archive/2017/03/genetic-discrimination-law-gina/519216/> pristupljeno 26. siječnja 2021.

57 Razlog tomu je izbjegavanje tzv. negativne selekcije, odnosno tendencije da osiguranik sa saznanjima o genetskoj sklonosti razvoja bolesti ugovara osigurateljsko pokriće, dok ostale osobe koje nemaju takvu genetsku predispoziciju neće biti zainteresirane za ugovaranjem navedenih pokrića. Aikin (n 56) 615.

58 Moratorium on Genetic Tests in Life Insurance (FSC Standard No 11, 21 June 2019) (AU) <https://www.fsc.org.au/resourcescategory/standard/1779-standard-11-moratorium-on-genetic-tests-in-life-insuran ce/file> pristupljeno 26. siječnja 2021.

59 Primjenom Moratorija de facto se onemogućava primjenu općih pravila ugovornog prava osiguranja o dužnosti prijavljivanja relevantnih okolnosti koje su osiguraniku/ugovaratelju osiguranja poznate, a odnose se na podatke iz genskih testova (čl. 21. st. 1. australskog Zakona o ugovoru o osiguranju); Insurance Contracts Act (No 80, 1984, compilation date 1 July 2016) (AU) <https://www.legislation.gov.au/Details/C2016C00820 p pristupljeno 26. siječnja 2021. 
guraniku (ne i nagovarati ih na obavljanje genskog testiranja) o dijagnozama zdravstvenog stanja makar takve dijagnoze proizlazile izravno ili neizravno iz genskog testa (čl. 3.1. i 3.2. Moratorija). No, o samim rezultatima genskog testiranja kao i o tome je li provedeno gensko testiranje, osigurateljima je dopušteno postavljati pitanja samo u slučajevima izričito navedenim u Moratoriju, a odnose se na visinu svote osiguranja i vrstu pokrića rizika obuhvaćenih životnim osiguranjem. Tako prema čl. 3.3. Moratorija osiguratelji se mogu koristiti genskim testovima ${ }^{61}$ ako: 1) svota osiguranja prelazi iznos od 500.000 australskih dolara za slučaj smrti ili trajne invalidnosti (death Cover, permanent disabilitiy Cover), 2) svota osiguranje prelazi iznos od 200.000 australskih dolara za slučaj tjelesne ozljede ili pojave teške bolesti (trauma and/or critical illness Cover) te 3) svota osiguranja prelazi iznos od 4.000 australskih dolara na mjesec za pokriće gubitka prihoda/plaće ili troškova poslovanja (income protection, salary continuance or business expenses Cover). U svim ostalim slučajevima, izvan navedenih, osiguratelj iz ugovora o osiguranju života se prema osiguraniku ne može ponašati kao prema kao osobi koja je prekršila svoje obveze prijave okolnosti značajnih za ocjenu rizika zbog neotkrivanja rezultata genskog testa (čl. 4.1. Moratorija).

\subsection{NJEMAČKA I AUSTRIJA}

U njemačkom pravu pitanje upotrebe podatka iz genskih testova u svrhu osiguranja uređuje Zakon o genskoj dijagnostici iz 2010. godine, ${ }^{62}$ koji uređuje korištenje podataka iz genskih testova, osim u osiguranju, i kod zapošljavanja, medicinskih istraživanja te kod utvrđivanja porijekla. ${ }^{63}$ Prema par. 18. navedenog Zakona, izrijekom je navedeno da osiguratelj ne može zahtijevati od osiguranika provođenje genskih testova ili analiza pri sklapanju ugovora o osiguranju, kao ni dostavu podataka i analiza iz genskih testova koju su poduzeti ranije (dakle, prije sklapanja ugovora o osiguranju), kao i podataka iz onih genskih testova koji su osiguranici samoinicijativno poduzeli za vrijeme trajanja ugovora o osiguranju. Oslobađanjem osiguranika/ ugovaratelja osiguranja dužnosti prijavljivanja podataka iz genskih testova ima za posljedicu da se osiguratelj ne može pozivati na odredbe par. 19. njemačkog Zakona o ugovoru o osiguranju (VVG-a) o dužnosti prijavljivanja okolnosti relevantnih za ocjenu rizika i posljedicama povrede takve obveze. Ipak, Zakon o genskoj dijagnostici poznaje iznimke od zabrane osigurateljima postavljati pitanja o provedenim genskim testiranjima. Pretpostavka za to jest da se osiguranici nisu podvrgnuli genskom testiranju na zahtjev osiguratelja (inicijativa za gensko testiranje mora dolaziti od strane osiguranika/ugovaratelja osiguranja, a ne od osiguratelja), a potom se traži ispunjenje još dviju pretpostavki: vrsta osigurateljskog pokrića i visina svote osiguranja. Osiguratelj ima pravo zatražiti podatke o provedenom genskom testiranju samo kod: 1) ugovora o osiguranju života (die Lebensversicherung), 2) ugovora o osiguranju od profesionalne nesposobnosti za rad (die Berufsunfähigkeitsversicherung), 3) ugovora o osiguranju

61 Onih genskih testova kojima su se osiguranici dobrovoljno podvrgnuli. Nije dopušteno da provedbu istih od njih zahtijevaju osiguratelji (čl. 3.2. t. 1 Moratorija).

62 Gesetz über genetische Untersuchungen bei Menschen (Gendiagnostikgesetz - GenDG) vom 31 Juli 2009 (BGBl I S. 2529, 3672) das zuletzt durch Artikel 23 des Gesetzes vom 20 November 2019 (BGBl I S. 1626) geändert worden ist (DE) (par 27 Zakona). 
gubitka prihoda za slučaj invalidnosti (die Erwerbsunfähigkeitsversicherung) te 4) ugovora o osiguranju tuđe pomoći i njege (die Pflegerentenversicherung). Pritom ugovorena svota osiguranja mora biti viša od 300.000 eura (jednokratno) ili više od 30.000 eura godišnje rente. Zakon o genskoj dijagnostici u par. 10. st. 2 izričito naglašava da ugovaratelj osiguranja/osiguranik ima obvezu prijaviti sve ostale okolnosti koje se odnose na njegovo zdravstveno stanje koji su mu dostupni bez provođenja genskog testiranja (npr. podaci iz liječničkog kartona ili podaci iz ostalih ne-genskih testova).

U austrijskom pravu pitanje korištenja genskih testova u svrhu osiguranja uređeno je Zakonom o genskoj tehnologiji iz 1994. godine (Gentechnikgesetz). ${ }^{64}$ Zakon izričito propisuje da se genski testovi mogu provoditi samo u medicinske svrhe (par. 65. st. 1. Zakona) te osiguratelji ne mogu zatražiti, prihvatiti ili na bilo koji način koristiti podatke iz genskih testova (par. 67. st. 1. reč. 2.). Osigurateljima se izričito zabranjuje primitak bilo koje tjelesne supstance u cilju provedbe njezine genetske analize (par. 67. st .1. reč. 2. Zakona) što predstavlja iskorak u odnosu na ostale propise iz poredbeno pravne analize. Ipak, austrijsko pravo poznaje i iznimku glede dijagnostičkih genskih testova te se dopušta korištenje podataka u svrhu osiguranja iz onih genskih testova koji služe za potvrdu postojeće bolesti, pripremu ili kontrolu terapije (par. 67. st. 2. t. 1. Zakona). Međutim, izrijekom se naglašava zabrana korištenja podataka u svrhu osiguranja iz genskih testova namijenjenih za utvrđivanje predispozicija razvoja bolesti (tzv. prediktivni genski testovi, par. 67. st. 2. t. 3. i 4. Zakona), kao i iz dijagnostičkih genskih testova koji se temelje na embrionalnoj mutaciji (par. 67. st. 2. t. 2. Zakona).

\subsection{FRANCUSKA I PORTUGAL}

Francusko pravo primjenjuje opću zabranu korištenja podataka iz genskih testova u svrhu osiguranja, a koja je izričito navedena u Zakoniku o osiguranju (Code des assurances). Naime, u osiguranju života kao i u osiguranju invalidnosti osiguratelji ne smiju uzimati u obzir rezultate genskog testiranja, čak i onda kada je takve rezultate predala osiguratelju sama osoba osiguranika ili je testiranje izvršeno uz njezinu suglasnost, niti je osigurateljima dopušteno postavljati pitanja o provedenim genskim testiranjima ili zahtijevati njihovo poduzimanje (čl. L1114-1 Zakonika).

U portugalskom pravu zabrana diskriminacije na temelju genetski uvjetovanje bolesti ili genetskog nasljeđa propisana je sukladno čl. 11. st. 1. Zakona o osobnim genskim i zdravstvenim podacima (Personal Genetic Information and Health Information Act) iz 2005 godine. ${ }^{65}$ Izričito se predviđa da se u zdravstvenom i životnom osiguranju ne smije diskriminirati osiguranike na temelju dijagnostičkih, prediktivnih ili prenatalnih genskih testova (čl. 11. st. 2. Zakona). U skladu s time, osiguratelji ne mogu zatražiti podvrgavanje svojih klijenata genskom testiranju, niti zahtijevati dostavu/prijavu rezultata genskog testiranja, a ne smiju koristiti ni bilo koju vrstu genske informacije koja im je već dostupna (npr. iz raznih medicinskih testova

64 Gentechnikgesetz (BGBl 510/1994, 73/1998, 98/2001, 94/2002, 73/2004, 127/2005, 13/2006, 111/2012, 114/2012, 35/2015, 92/2015, 126/2015, 112/2016, 37/2018, 59/2018) (AT)

65 Personal Genetic Information and Health Information Act (Law 12/2005 of 26 January) (PT) <https://www.eshg.org/fileadmin/ www.eshg.org/documents/Europe/LegalWS/Portugal_Law-UnofficialEnglish Translation.pdf>pristupljeno 26. siječnja 2021. 
koji su već ranije poduzeti na njihovim klijentima iz bilo kojeg razloga) (čl. 12. Zakona). Dakle, portugalsko pravo, slično kao i francusko uvodi apsolutnu zabranu korištenja genskog testiranja u svrhu osiguranja, bez dopuštenih iznimaka.

\subsection{NAČELA EUROPSKOG UGOVORNOG PRAVA OSIGURANJA}

Načela europskog ugovornog prava osiguranja ${ }^{66}$ također sadržavaju odredbe o mogućnosti korištenja podataka iz genskih testova u svrhu osiguranja. Načelno, NEUPO brani korištenje genskih testova u svrhu osiguranja. Izrijekom je predviđeno da osiguratelj ne može zahtijevati da se ugovaratelj osiguranja, odnosno osiguranik podvrgnu genskom testiranju, niti su mu dužni prijaviti rezultate genskih testova ako su ih već obavili. Ako kojim slučajem osiguratelj raspolaže podacima iz genskih testova, ne smije iste ni u kojem slučaju koristiti za procjenu stupnja rizika (čl. 1:208 st. 1. NEUPO-a). Ali, predviđen su određeni izuzeci, slični onima iz prikazanih poredbenopravnih sustava. Osiguratelj može koristiti rezultate genskih testova ako su osigurane osobe starije od 18 godina i ako osigurana svota iznosi više od 300.000 eura, odnosno kada je novčani iznos koji se isplaćuje po polici viši od 30.000 eura na godinu (čl. 1:208, st. 2. NEUPO-a). No, ipak prijavljivanje podataka iz genskih testova dobrovoljne je naravi, odnosno ako se takvi podaci ne prijave, ne primjenjuju se odredbe o posljedicama povrede obveze (pred)ugovornog prijavljivanja okolnosti značajnih za ocjenu rizika (čl. 2:106 NEUPO-a).

\section{NEMOGUĆNOST KORIŠTENJA PODATAKA IZ GENSKIH TESTOVA U SVRHU OSIGURANJA PREMA HRVATSKOM PRAVU}

U hrvatskom pravu postoji nekoliko propisa koji se jednim dijelom odnose na (ne)mogućnosti korištenja genskih testova u svrhu osiguranja. Načelna nemogućnost korištenja podataka iz genskih testova proizlazi iz Zakona o zaštiti prava pacijenata ${ }^{67}$ te iz Zakona o suzbijanju diskriminacije. ${ }^{68}$ Izričitu zabranu obrade genskih podataka u svrhu osiguranja nalazimo u čl. 20. Zakona o provedbi Opće uredbe o zaštiti osobnih podataka. ${ }^{69}$

Načelno je propisano da se genski testovi koji ukazuju na bolesti ili služe za identifikaciju pacijenata mogu obavljati samo u zdravstvene svrhe ili radi znanstvenog istraživanja vezanog

66 Principles of European Insurance Contract Law/PEICL, (dalje: NEUPO) predstavlja akademski tekst, neobvezujućeg pravnog karaktera kojemu je bio cilj koncipirati unificirana pravila privatnog ugovornog prava osiguranja koja bi se na jedinstveni način primjenjivala na području Europske unije, odnosno na cjelokupnom europskom tržištu osiguranja, te poslužiti kao završni dokument tijelima Unije radi donošenja političkih odluka u vezi s harmonizacijom ugovornog prava osiguranja u Uniji. Prva verzija Načela objavljena je 2009. godine, a izmijenjena i dopunjena verzija 2016. godine. Tatjana Josipović, Privatno pravo Europske unije - opći dio (Narodne novine 2020) 925-26; Principles of European Insurance Contract Law - PEICL (1 November 2015) <https://www.uibk.ac.at/zivilrecht/forschung/evip/restatement/sprachfassungen/peicl-en.pdf> pristupljeno 26. siječnja 2021. 
u zdravstvene svrhe, i to uz odgovarajuće genetsko savjetovanje (čl. 22. st. 2. ZZPP-a). Nadalje, zabranjena je i diskriminacija, odnosno stavljanje u nepovoljni položaj pojedinaca, među ostalim i na osnovi genetskog naslijeđa (čl. 1. st. 1. i 2. ZSD-a).

Ovako načelno postavljene odredbe, kao prvo, argumentum a contrario, ne dopuštaju obavljanje genskih testova u neke druge svrhe osim zakonom propisane, pa tako niti u svrhu osiguranja, tj. za procjenu stupnja rizika te u vezi s odlukom o isključenjima ili ograničenjima iz osigurateljskog pokrića, visini premije i slično. Kao drugo, ako osiguratelj, zbog nekog razloga, raspolaže podacima iz genskih testova, nije mu dopušteno na temelju toga diskriminirati osiguranika, a što se očituje ili odbijanjem ponude za ugovaranjem osiguranja ili zahtijevanjem plaćanja više stope premije kao posljedicom nepovoljnih rezultata genskih testova osiguranika. Prijava povoljnih rezultata genskih testova svakako bi mogla biti u interesu osiguranika jer to može značiti i nižu premiju, odnosno širi opseg pokrića rizika, ali prema ZZPP-u osiguratelj niti "povoljne" podatke iz genskih testova, ne smije koristiti u svrhu osiguranja.

Pri donošenju ZPOUZP-a 2018. godine, hrvatski se zakonodavac, u skladu s Uredbom postavljenim posebnim statusom genskih podataka, odlučio na izričitu zabranu korištenja rezultata prediktivnih testova u svrhu sklapanja ili izvršavanja ugovora o životnom osiguranju i ugovora s klauzulama o doživljenju. Tako čl. 20. st. 1. ZPOUZP-a izričito zabranjuje obradu "genskih podataka radi izračuna izgleda bolesti i drugih zdravstvenih aspekata ispitanika, u okviru radnji za sklapanje ili izvršavanje ugovora o životnom osiguranju i ugovora s klauzulama o doživljenju." ${ }^{\prime 0}$ Također, u skladu s čl. 9. st. 2. t. a Uredbe, naglašava da se pristankom ispitanika ne može ukinuti navedena zabrana (čl. 20. st. 2. ZPOUZP-a). Propisana zabrana ima za cilj spriječiti bilo kakvu mogućnost da osiguratelji postavljaju upitnike o provedenim genskim testiranjima, što uključuje i zabranu da se od osiguranika zatraži obavljanje genskog testiranja, na način kao što se može zatražiti liječnički pregled pri sklapanju ugovora o osiguranju, sukladno čl. 925. st. 4. ZOO-a. Čak i ako ispitanik/osiguranik daje izričiti pristanak za obradu podataka iz genskih testova, takav će pristanak biti bez pravnog učinka jer je protivna zakonskoj zabrani koja djeluje apsolutno. Područje primjene ovakve zabrane, prema izričitoj zakonskoj odredbi, odnosi se na ugovor o životnom osiguranju te na ugovore s klauzulama o doživljenju. S pravom se postavlja pitanje zašto navedenom zabranom primjerice nije obuhvaćeno i zdravstveno osiguranje kao što je to slučaj u poredbenom zakonodavstvu. ${ }^{71}$ Stoga, glede ostalih vrsta ugovora o osiguranju primjenjuju se pravila obrade genskih podataka kao

70 Spomenuti ugovor s klauzulama o doživljenju zapravo je jedna od vrsta ugovora o osiguranju života. Naime, kod ugovora o osiguranju života osigurnina se isplaćuje korisniku osiguranja (koji i ne mora biti izričito određen ugovorom) ako osiguranik umre za trajanja ugovorenog osiguranja (osiguranje za slučaj smrti, riziko osiguranje života) ili na kraju trajanja osiguranja ako je osiguranik na životu, odnosno ako doživi unaprijed ugovoreni datum (osiguranje doživljenja). No, vrlo često je moguće da obveza isplate osigurnine postoji u oba slučaja, a osigurnina se isplaćuje ovisno o tome koji se slučaj prvi ostvari (smrt ili doživljenje). Tu je riječ o tzv. mješovitom osiguranju života. Sanja Andrijašević i Tatjana Račić-Žlibar, Rječnik osiguranja, (Masmedia 1997) 307-08.

71 Osim već spomenutih pravnih uređenja gdje se ne dopušta obavljanje genskih testova u svrhu zdravstvenog osiguranja (SAD, Velika Britanija, Njemačka i dr.) na ovom mjestu smatramo potrebnim ukazati da izričita zabrana korištenja podatka iz genskih testova kod dobrovoljnih zdravstvenih osiguranja postoji u srpskom pravu. Prema čl. 13. Uredbe o dobrovoljnom zdravstvenom osiguranju (SG 108/2008, 49/2009) (RS) pri sklapanju ugovora o dobrovoljnom zdravstvenom osiguranju, zabranjeno je da "davatelj osiguranja" traži genske podatke, odnosno rezultate genskih testova za određene nasljedne bolesti za osobu koja iskaže jasnu namjeru da želi s tim davateljem osiguranja sklopiti ugovor o osiguranju, kao i za njegove srodnike bez obzira na stupanj srodstva. Pojedini autori predlažu proširenje takve zabrane u pogledu ostalih vrsta osiguranja. Katarina Ivančević, 'Diskriminacija i osiguranje' u Slobodan Jovanović i Pierpaolo Marano (eds), Pravo i praksa osiguranja: izazovi, nove tehnologije i korporativno upravljanje: zbornik radova XIX. savjetovanja (Udruženje za prava osiguranja Srbije i Udruženje osiguravača Srbije 2018) 292. 
posebne kategorije osobnih podataka iz Uredbe te načelne odredbe ZZPP-a i ZSD-a. To može u praksi otvoriti mogućnost da glede takvih osiguranja osiguratelj zatraži informacije o provedenim genskim testiranjima uz pristanak samog osiguranika/ugovaratelja osiguranja, budući da se zabrana obrade takvih podataka iz čl. 9. st. 1. Uredbe ne primjenjuje ako je za nju ispitanik dao izričiti pristanak, osim kada je posebno propisano da pristanak ne može ukinuti zabranu njihove obrade (čl. 9. st. 2. t. a Uredbe).

\section{OGRANIČENJA U POGLEDU GENSKIH PODATAKA SRODNIKA}

Nije novost da su pitanja o bolestima u obitelji uobičajeno dio upitnika pri ugovaranju, primjerice, životnih osiguranja ili dobrovoljnih zdravstvenih osiguranja. ${ }^{72} \mathrm{Na}$ temelju tako prikupljenih podataka osiguratelji donose odluku o osigurateljskom pokriću. Međutim, genetski testovi, za razliku od tradicionalnih upitnika, pružaju mnogo specifičniju informaciju glede rizika od pojave bolesti u obitelji, odnosno među krvnim srodnicima. ${ }^{73}$ Upravo zbog toga, a zbog dosljednosti zaštite osiguranika od diskriminacije u osiguranju, pojedini propisi u poredbenom pravu (poglavito onih zemalja u kojima nije uvedena apsolutna zabrana korištenja genskih informacija u svrhu osiguranja), postojeća ograničenja u korištenju podataka iz genskih testova u svrhu osiguranja proširuju i na srodnike, odnosno članove obitelji osiguranika. ${ }^{74}$ Prema britanskom pravu osiguratelj ne može zahtijevati podatke iz genskih testova krvnog srodnika (ili bilo koje druge osobe) za ocjenu rizika pojave bolesti kod osiguranika (čl. 3. st. b. Kodeksa). U američkom (saveznom) pravu zabranjuje se osiguratelju zdravstvenog osiguranja zatražiti podvrgavanje članova obitelji osiguranika genskom testiranju ili informiranje o rezultatima takvih testova (čl. 101. st. c1. i c2., GINA-e). Hrvatsko pravo, koje ne dopušta korištenje podataka iz genskih testova u svrhu osiguranja života, odnosno u pogledu ostalih vrsta osiguranja načelno zabranjuje diskriminaciju na temelju genetskog nasljeđa ne sadrži izričitu odredbu o zabrani diskriminacije zbog genskih karakteristika srodnika. ${ }^{75}$ Možda bi radi potpunog ostvarivanja proklamiranih načela i pravila o sprječavanju korištenja podatka iz genskih testova u svrhu osiguranja trebalo de lege ferenda razmisliti i o mogućnosti izričitog propisivanja identičnih zabrana i za krvne srodnike osiguranika/ugovaratelja osiguranja, a što bi bilo u skladu i s Preporukom Vijeća Europe (supra 2.1.).

72 Ćurković (n 4) 76-77.

73 Beatrice Godard and others, 'Genetic Information in Testing Insurance and Employment: Technical, Social and Ethical Issues' (2003) 11(2) European Journal of Human Genetics 125.

74 Naime, podaci iz genskih testova mogu stigmatizirati čitave grupe pojedinaca koja su rodbinski povezane, što bi dovelo do stvaranja tzv. genskih potklasa, odnosno skupina ljudi za koje postoji opasnost od diskriminacije na osnovi genskog nasljeđa, bar što se tiče pristupu usluga osiguranja. Elizabeth Adjin-Tettey, 'Potential for Genetic Discrimination in Access to Insurance: Is There a Dark Side to Increased Availability of Genetic Information?' (2013) 50(3) Alberta Law Review 594.

75 Takvu izričitu odredbu međutim sadržava srpski Zakon o prevenciji i dijagnostici genetičkih bolesti, genetički uslovljenih anomalija i retkih bolesti (SG 8/2015) (RS) u čl. 9 prema kojem nitko ne smije biti diskriminiran niti doveden u nepovoljan položaj zbog njegovih genskih karakteristika, genskih osobina njegovih srodnika ili zbog samog podvrgavanja ili nepodvrgavanja genetskom ispitivanju. 


\section{PROBLEM ŠIROKE DOSTUPNOSTI GENSKIH TESTOVA I OSIGURANJE}

U današnje vrijeme na tržištu prisutan je velik broj genskih (i drugih) testova koji su dostupni gotovo svakome. Riječ je o tzv. direct-to-consumer (DTC) genskim testovima koje razne biotehnološke kompanije oglašavaju preko raznih kanala, a najčešće na internetu. ${ }^{76}$ Korištenjem takvih testova omogućava se pojedincima informiranje i procjena rizika pojave genetski uvjetovanih bolesti ili se pak mogu koristiti za neke druge nemedicinske svrhe (npr. u svrhu utvrđivanja porijekla, procjene sportskih ili nekih drugih karakteristika ispitanika i slično).

Međutim, obavljanje takvog testiranja izloženo je raznim kritikama ${ }^{77}$ kojima se ukazuje na moguće zablude korisnika/ispitanika, a time se dovodi u pitanje i njegova opravdanost. ${ }^{78} \mathrm{Ta}$ kođer, ističu se i moguće zlouporabe osobnih tj. genskih podataka kojima raspolažu kompanije koje provode takvo testiranje (naročito opasnost koju donosi trgovina takvim podatcima ili njihova dostupnost trećima u slučaju stečaja takvih kompanija), kao što se postavlja i pitanje etičnosti genskog testiranja maloljetnika DTC genskim testovima. ${ }^{79}$

Navedena sporna pitanja široke dostupnosti genskog testiranja prepoznata su i na međunarodnoj razini te se u već spomenutim međunarodnim regulatornim okvirima (supra 2.1.) ona pokušavaju riješiti. Nameću se razna ograničenja u korištenju genskih testova, odnosno propisuju pretpostavke za njihovo korištenje (klinička korist, medicinski nadzor, gensko savjetovanje, informirani pristanak). Usto su pojedine države samostalno uredile mogućnosti korištenja genskih testova, pri čemu nisu prisutna jedinstvena rješenja. ${ }^{80}$

I u tzv. industriji osiguranja prepoznata su spomenuta sporna pitanja pa se postojećim propisima o ograničenju korištenja genskih testova u svrhu osiguranja nastoji spriječiti korištenje neprovjerenih i “sumnjivih” genskih testova. Tako je u pravu Velike Britanije Kodeksom o genskom testiranju u osiguranju propisano kako osiguratelji mogu koristiti samo one prediktivne genske testove koji su izričito odobreni i nalaze se u popisu Dodatka I Kodeksa (čl. 2. st. 2. Kodeksa). Prema trenutačno važećoj listi u spomenutom Dodatku I ${ }^{81}$ osiguratelji smiju zatražiti prijavu podataka samo o provedenom genskom testu koji se odnosi na Huntingtonovu bolest ${ }^{82}$ i to samo za pokriće iz ugovora o osiguranju života s osiguranom svotom iznad 500.000 funti. ${ }^{83}$ Dakle, u svrhu osiguranja ne mogu se uvažavati rezultati genskih testova koji

76 Louiza Kolakairinou and others, 'Legislation of Direct-to-consumer Genetic Testing in Europe: A Fragmented Regulatory Landscape' (2018) 9 Journal of Community Genetics 118.

77 Vidi fusnotu 1.

78 Fukuda (n 1) 52; Borry (n 1) 715.

79 Kolakairinou (n 77) 118.

8o Vidi usporedbu zakonskih uređenja prema državama u: Kolakairinou (n 77) 120, 123, 125.

81 Dodatak I nalazi se na str. 14. Kodeksa.

82 Genski test na Huntingtonovu bolest ukazuje sa stopostotnom (100\%) sigurnošću da će osoba s pozitivnim testom kasnije u životu razviti takvu bolest, pa je zapravo pozitivan test na spomenutu bolest ujedno i njezina definitivna dijagnoza. S druge strane, primjerice kod bolesti kao što su Parkinsonova ili Alzheimerova bolest utvrđena prisutnost genskih pokazatelja njihova nastanka ne znači ujedno i konačnu dijagnozu tih bolesti, već samo ukazuju na određen stupanj povećanog rizika. Aikin (n 56) 603-04.

83 No kako bi se suzbila moguća samovolja osiguratelja pri odlučivanju o pružanju osigurateljnog pokrića na temelju obavljenih genskih testova, Kodeks ovlašćuje osiguranika/ugovaratelja osiguranja zatražiti objašnjenje od osiguratelja jesu li i kako rezultati 
nisu unaprijed odobreni i ne nalaze se na listi Kodeksa. ${ }^{84} \mathrm{I}$ u australskom pravu poklanja se pozornost medicinskom savjetovanju ako se genski testovi koriste u svrhu osiguranja života. Naime, izrijekom je predviđeno da osiguratelj mora omogućiti svojim djelatnicima savjetovanje s medicinskim stručnjacima ako se rezultat genskog testa smatra relevantnim u procjeni rizika osiguranja (čl. 3.7. Moratorija). Njemačko pravo također propisuje obvezu savjetovanja pojedinaca od strane kvalificiranih liječnika prije obavljanja genetskog testiranja, neovisno o tome obavlja li se testiranje u svrhu osiguranja ili ne (par. 9. i 10. njemačkog Zakona o genskoj dijagnostici).

\section{ZAKLJUČAK}

Potreba za zaštitom podataka iz genskih testova prepoznata je u raznim međunarodnim pravnim aktima i aktima Europske unije. Mogućnost korištenja genskih tehnologija u svrhu osiguranja takvu potrebu još i više naglašava, no i dalje bez općeprihvaćenog i pravno obvezujućeg rješenja na međunarodnoj razini, ali i u Europskoj uniji. Također je razvidno da zaštita podataka iz genskih testova kao osobnih podataka nije apsolutna ako postoji pristanak ispitanika.

Iz provedene poredbenopravne analize proizlaze zaključci da se mogućnosti korištenja genskih testova u svrhu osiguranja kreću od liberalnijeg pristupa prema potpunoj zabrani. Izvjesne razlike prisutne su i u uređenjima država članica Europske unije, iako postoji zajednički obvezni okvir zaštite podataka iz genskih testova kao posebne kategorije osobnih podataka. Potrebno je naglasiti kako u nijednom od analiziranih sustava ne postoji apsolutna slobodna u korištenju genskih testova u svrhu osiguranja, već su kod svih prisutna određena ograničenja. Liberalniji pristup imaju države common law sustava u odnosu na države kontinentalne Europe. Najliberalniji pristup nalazimo u pravu SAD-a gdje se zabrana genskih testova na saveznoj razini odnosi samo na zdravstveno osiguranje pojedinaca, dok je glede svih ostalih vrsta osiguranja to prepušteno zakonodavstvu pojedinih saveznih država. Potom slijede Velika Britanija, Australija pa i Njemačka koje načelno zabranjuju korištenje podataka iz genskih testova u svrhu osiguranja, osim za pojedine vrste osiguranja (kao što su osiguranje života, osiguranje prihoda, osiguranje od teških bolesti i invalidnosti) i samo ako je ugovorena svota osiguranja

provedenog genskog testiranja utjecali na odluku osiguratelja o pokriću, premiji osiguranja i eventualnim isključenjima iz pokrića. Ako po dobivenoj informaciji, osiguranik/ugovaratelj osiguranja smatra da osiguratelj nije postupao u skladu s Kodeksom, može podnijeti pritužbu nadležnim službama osiguratelja, a dodatno nakon toga može podnijeti i prijavu pravobraniteljstvu za djelatnost osiguranja te tijelu nadležnom za nadzor u osiguranju. Pored toga, osiguratelji su dužni podnositi godišnja izvješća Udruženju britanskih osiguratelja i Vladi radi nadgledanja provedbe Kodeksa. (Pitanja i odgovori glede Kodeksa, str. 10-11). Posebnu važnost pridaje se djelatnicima osiguratelja zaduženim za preuzimanje genskih rizika koje mora imenovati svaki osiguratelj sukladno svojoj veličini (tzv. Nominated Genetics Underwriter - NGU) (čl. 8. Kodeksa). Takvi djelatnici moraju biti posebno obrazovani te su odgovorni za sva pitanja glede genetskog testiranja u svrhu osiguranja. Njihove su dužnost posebno propisane u Dodatku II Kodeksa (str. 15-16). Ovdje izdvajamo neke od njih: da je u toku s relevantnim dostignućem genske znanosti i tehnologije; pomoć u osposobljavanju ostalog osoblja osiguratelja glede preuzimanja genskih rizika; voditi dnevnik genskog testiranja; savjetovati se s liječničkom strukom o značenju podataka iz genskih testova; voditi dnevnik pritužbi koje se odnose na kršenja Kodeksa; izvijestiti interne službe nadležne za rješavanje prigovora/pritužbi o mogućim povredama Kodeksa te pružati potporu u procesu rješavanje prigovora/pritužbi.

84 Zbog toga se u dodatnim objašnjenjima uz Kodeks navodi mogućnost njegova stalnog ažuriranja u suradnji Udruženja britanskih osiguratelja i Vlade kako bi Kodeks bio u skladu s najnovijim dostignućima genomske medicine (Pitanja i odgovori glede Kodeksa, str. 11). 
iznad propisanog limita. Konačno, nalazimo i države poput Francuske, Portugala, Austrije, ali i Hrvatske gdje je izričito propisana zabrana korištenja genskih testova u svrhu osiguranja.

S obzirom na to da u Europskoj uniji postoje primjeri uvjetne dopustivosti primjene genskih testova u svrhu osiguranja (Njemačka), uz očekivani daljnji razvoj genske tehnologije (a u koju, među ostalim, investiraju upravo osiguratelji) koja će omogućiti kvalitetnija i preciznija genska testiranja, nije isključena pojava zahtjeva za uvođenjem liberalnijeg pristupa u korištenju podataka iz genskih testova u svrhu osiguranja. Ovo zbog dva razloga: prvi, što zasad ni u jednom dokumentu Europske unije ne nalazimo apsolutnu zabranu korištenja genskih testova u svrhu osiguranja koja bi se primjenjivala beziznimno za sve države članice, a drugi se odnosi na postizanje jednakosti tržišnih uvjeta na čitavom području Unije - ako makar u jednoj državi članici, kao što je Njemačka, osiguratelji mogu koristiti genske testove u svrhu osiguranja (doduše, zasad, vrlo ograničeno), takvi osiguratelji su "povlašteni" u odnosu na osiguratelje u ostalim državama članicama gdje je propisana apsolutna zabrana korištenja genskih testova u svrhu osiguranja. No, ostvarenje liberalizacije korištenja genskih testova u svrhu osiguranja u Uniji nije moguće postići bez jedinstvenog pristupa u regulaciji navedenog pitanja, a što u ovom trenutku nedostaje.

\section{BIBLIOGRAFIJA}

1. Adjin-Tettey E, 'Potential for Genetic Discrimination in Access to Insurance: Is There a Dark Side to Increased Availability of Genetic Information?' (2013) 50(3) Alberta Law Review 577

2. Aikin A, 'Contradiction in Terms: Genetic Nondiscrimination and Long-Term Care Insurance' (2016) 53(4) University of Louisville Law Review 597

3. Andrijašević S i Račić-Žlibar T, Rječnik osiguranja (Masmedia 1997)

4. Bevanda M i Čolaković M, 'Pravni okvir za zaštitu osobnih podataka (u vezi sa zdravljem) u pravu Europske unije’ (2016) 37(1) Zbornik Pravnog fakulteta Sveučilišta u Rijeci 125

5. Bodiroga Vukobrat N i Horak H, 'Pravni okvir zaštite podataka u digitalnoj ekonomiji: ograničenje ili poticaj zaštiti osobnih podataka' u Zvonimir Slakoper, Maja Bukovac Puvača i Gabrijela Mihelčić (eds), Liber amicorum Aldo Radolović: Zbornik radova u čast prof. dr. sc. Aldu Radoloviću (Pravni fakultet u Rijeci 2018) 301-315

6. Bodiroga-Vukobrat $\mathrm{N}$ and Horak H, 'Challenges of Personalized Medicine: Socio-Legal Disputes and Possible Solutions' in Nada Bodiroga-Vukobrat and others (eds), Personalized Medicine: A New Medical and Social Challenge (Springer 2016) 31-51

7. Borry P and others, 'Legislation on Direct-to-consumer Genetic Testing in Seven European Countries' (2012) 20 European Journal of Human Genetics 715

8. Bukovac Puvača M i Demark A, 'Pravo na zaštitu osobnih podataka kao temeljno pravo i odgovornost za štetu zbog njegove povrede' (2019) 40(1) Zbornik Pravnog fakulteta Sveučilišta u Rijeci 287

9. Ćurković M, Ugovor o osiguranju: Komentar odredaba Zakona o obveznim odnosima (Inženjerski biro 2017)

10. Davey J, 'Genetic Discrimitantion in Insurance: Lessons from Test Achats' in Gerard Quinn, Aisling de Paor and Peter Blanck (eds), Genetic Discrimination, Transatlantic Perpectives on the Case for European Legal Response (Routledge 2015) 143-60 
11. De Paor A and Ferri D, 'Regulating Genetic Discrimination in the European Union, Pushing the EU into Unchartered Territory or Unshering in a New Genomic Era' (2015) 17(1) European Journal of Law Reform 14

12. De Paor A, 'Advancing Science and Controlling the Misuse of Genetic Information in Employment and Insurance: Towards an Effective European Union Regulatory Framework' (PhD thesis, School of Law, National University of Ireland 2013)

13. Dulčić K i Bodiroga Vukobrat N, 'Zaštita osobnih podataka pacijenata u europskom i hrvatskom pravu’ (2008) 29(1) Zbornik Pravnog fakulteta Sveučilišta u Rijeci 371

14. Fukuda $\mathrm{R}$ and Takada $\mathrm{F}$, 'Legal regulations on health-related direct-to-consumer genetic testing in 11 countries' (2018) 48 Kitasato Medical Journal 52

15. Godard B and others, 'Genetic Information in Testing Insurance and Employment: Technical, Social and Ethical Issues' (2003) 11(2) European Journal of Human Genetics 123

16. Ivančević K, 'Diskriminacija i osiguranje’ u Slobodan Jovanović i Pierpaolo Marano (eds), Pravo i praksa osiguranja: izazovi, nove tehnologije i korporativno upravljanje: zbornik radova XIX. savjetovanja (Udruženje za prava osiguranja Srbije i Udruženje osiguravača Srbije 2018) 278-96

17. Josipović T, Privatno pravo Europske unije: opći dio (Narodne novine 2020)

18. Keglević A, Ugovorno pravo osiguranja (Školska knjiga 2016)

19. Kolakairinou L and others, 'Legislation of Direct-to-consumer Genetic Testing in Europe: A Fragmented Regulatory Landscape' (2018) 9 Journal of Community Genetics 117

20. Pavić D, Ugovorno pravo osiguranja (Tectus 2009)

21. Sándor J (ed), UNESCO i bioetika: zbirka osnovnih dokumenata (Center for Ethics and Law in Biomedicine 2008)

22. Stirton R, 'Insurance, Genetic Information and the Future of Industry Self-Regulation in the UK' (2012) 4(2) Law, Innovation and Technology 212

23. Taylor M, Genetic Data and the Law: A critical Perspective on Privacy Protection (Cambridge University Press 2012)

24. Varga O and others, 'Definitions of Genetic Testing in European Legal Documents' (2012) 3 Journal of Community Genetics 125

\section{PROPISI I DOKUMENTI}

1. Code des assurances = Zakonik o osiguranju (FR) <http://www.legifrance.gouv.fr/affichCode . do?cidTexte=LEGITEXT000006073984> pristupljeno 26. siječnja 2021.

2. Code on Genetic Testing and Insurance (UK) <https://www.abi.org.uk/data-and-resources/ tools-and-resources/genetics/code-on-genetic-testing-and-insurance> pristupljeno 26. siječnja 2021.

3. Council of Europe, Additional Protocol to the Convention on Human Rights and Biomedicine, concerning Genetic Testing for Health (Council of Europe Treaty Series No 203, 2008) <https://rm.coe. int/1680084824> pristupljeno 26. siječnja 2021.

4. Gentechnikgesetz (BGBl 510/1994, 73/1998, 98/2001, 94/2002, 73/2004, 127/2005, 13/2006, 111/2012, 114/2012, 35/2015, 92/2015, 126/2015, 112/2016, 37/2018, 59/2018) (AT) 
5. Gesetz über den Verisherungsvertrag (Versicherungsvertragsgesetz - VVG) vom 23 November 2007 (BGBl I S. 2631), das zuletzt durch Artikel 2 des Gesetzes vom 10 Juli 2020 (BGBl I S. 1653) geändert worden ist (DE)

6. Gesetz über genetische Untersuchungen bei Menschen (Gendiagnostikgesetz - GenDG) vom 31 Juli 2009 (BGBl I S. 2529, 3672) das zuletzt durch Artikel 23 des Gesetzes vom 20 November 2019 (BGBl I S. 1626) geändert worden ist (DE)

7. Insurance Contracts Act (No 80, 1984, compilation date 1 July 2016) (AU) <https://www.legislation.gov.au/Details/C2016C00820> pristupljeno 26. siječnja 2021.

8. International Declaration on Human Genetic Data (16 October 2003) <https://en.unesco.org/ themes/ethics-science-and-technology/human-genetic-data> pristupljeno 20. siječnja 2021.

9. Ispravak Uredbe (EU) 2016/679 Europskog parlamenta i Vijeća od 27. travnja 2016. o zaštiti pojedinaca u vezi s obradom osobnih podataka i o slobodnom kretanju takvih podataka te o stavljanju izvan snage Direktive 95/46/EZ (Opća uredba o zaštiti podataka) [2018] SL L127/2

10. Moratorium on Genetic Tests in Life Insurance (FSC Standard No 11, 21 June 2019) (AU) $<$ https://www.fsc.org.au/resources-category/standard/1779-standard-11-moratorium-on-genetic-tests-in-life-insurance/file> pristupljeno 26. siječnja 2021.

11. Odluka o objavi Opće deklaracije o ljudskim pravima (NN-MU 12/09) (HR)

12. Opća deklaracija o ljudskim pravima (usvojena i proglašena Rezolucijom Opće skupštine Ujedinjenih naroda 217A/III, 10. prosinca 1948.)

13. Personal Genetic Information and Health Information Act (Law 12/2005 of 26 January) (PT) <https://www.eshg.org/fileadmin/www.eshg.org/documents/Europe/LegalWS/Portugal_Law-UnofficialEnglishTranslation.pdf> pristupljeno 26. siječnja 2021.

14. Povelja Europske unije o temeljnim pravima (2016/C 202/02) [2016] SL C202/389

15. Principles of European Insurance Contract Law - PEICL (1 November 2015) <https://www.uibk. ac.at/zivilrecht/forschung/evip/restatement/sprachfassungen/peicl-en.pdf> pristupljeno 26. siječnja 2021.

16. Recommendation $\mathrm{CM} / \operatorname{Rec}(2016) 8$ of the Committee of Ministers to the member States on the processing of personal health-related data for insurance purposes, including data resulting from genetic tests (Adopted by the Committee of Ministers on 26 October 2016 at the 1269th meeting of the Ministers' Deputies) <https://search.coe.int/cm/Pages/result_details.aspx?ObjectID=09000016806b2c5f > pristupljeno 26. siječnja 2021.

17. The Genetic Information Nondiscrimination Act of 2008, Public Law 110-233, 122 Stat 881 (21 May 2008) (US)

18. The Patient Protection and Affordable Care Act of 2010, Public Law 111-148, 124 Stat 119, (23 March 2010) (US)

19. Ugovor o funkcioniranju Europske unije (pročišćena verzija) [2016] SL C202/47

20. Universal Declaration on Bioethics and Human Rights (adopted by UNESCO's General Conference on 19 October 2005) <https://en.unesco.org/themes/ethics-science-and-technology/bioethics-and-human-rights> pristupljeno 26. siječnja 2021.

21. Universal Declaration on the Human Genome and Human Rights (UNESCO, 11 November 1997) $<$ https://en.unesco.org/themes/ethics-science-and-technology/human-genome-and-humanrights > pristupljeno 26. siječnja 2021.

22. Uredba (EU) 2016/679 Europskog parlamenta i Vijeća od 27. travnja 2016. o zaštiti pojedinaca u vezi s obradom osobnih podataka i o slobodnom kretanju takvih podataka te stavljanju izvan snage Direktive 95/46/EZ (Opća uredba o zaštiti podataka) [2016] SL L119/1 
23. Uredba o dobrovoljnom zdravstvenom osiguranju (SG 108/2008, 49/2009) (RS)

24. Zakon o obveznim odnosima (NN 35/2005, 41/2008, 125/2011, 78/2015, 29/2018) (HR)

25. Zakon o potvrđivanju Konvencije o zaštiti ljudskih prava i dostojanstva ljudskog bića u pogledu primjene biologije i medicine: Konvencije o ljudskim pravima i biomedicini, Dodatnog protokola uz Konvenciju o zaštiti ljudskih prava i dostojanstva ljudskog bića u pogledu primjene biologije i medicine o zabrani kloniranja ljudskih bića i Dodatnog protokola uz Konvenciju o zaštiti ljudskih prava i dostojanstva ljudskog bića u pogledu primjene biologije i medicine, u vezi presađivanja organa i tkiva ljudskog porijekla (NN-MU 13/2003) (HR)

26. Zakon o potvrđivanju Konvencije za zaštitu ljudskih prava i temeljnih sloboda i Protokola br. 1., 4., 6., 7., i 11. uz Konvenciju za zaštitu ljudskih prava i temeljnih sloboda (NN-MU 18/1997) (HR)

27. Zakon o prevenciji i dijagnostici genetičkih bolesti, genetički uslovljenih anomalija i retkih bolesti (SG 8/2015) (RS)

28. Zakon o provedbi Opće uredbe o zaštiti osobnih podataka (NN 42/2018) (HR)

29. Zakon o suzbijanju diskriminacije (NN 85/2008, 112/2012) (HR)

30. Zakon o zaštiti prava pacijenata (NN 169/2004, 37/2008) (HR)

\section{PRESUDE I DRUGE ODLUKE}

1. Case C-236/09 Association belge des Consommateurs Test-Achats ASBL, Yann van Vugt, Charles Basselier v Conseil des ministres [1 March 2011] ECLI:EU:C:2011:100

\section{MREŽNI IZVORI}

1. - - Code on Genetic Testing and Insurance: Annual Report 2019 (The Association of British Insurers 2019) <https://www.abi.org.uk/globalassets/files/publications/public/genetics/abi-2019-annualreport-on-code-on-genetic-testing-and-insurance.pdf> pristupljeno 26. siječnja 2021.

2. Chart of signatures and ratifications of Treaty 203 (Additional Protocol to the Convention on Human Rights and Biomedicine concerning Genetic Testing for Health Purposes) <https://www.coe. int/en/web/conventions/full-list/-/conventions/treaty/203/signatures?p_aut h=rLWABa1h> pristupljeno 26. siječnja 2021.

3. Zhang S, 'The Loopholes in the Law Prohibiting Genetic Discrimination' The Atlantic (13 March 2017) <https://www.theatlantic.com/health/archive/2017/03/genetic-discrimination-law-gina/519216/> pristupljeno 26. siječnja 2021. 


\section{THE CHALLANGES OF REGULATING THE USE OF PERSONAL DATA FROM GENETIC TESTS FOR INSURANCE PURPOSES}

\section{Summary}

The paper deals with the issue of using genetic tests for insurance purposes. After introductory remarks, the paper provides an overview of various international and European legal sources both on data protection in general, and on the protection of data from genetic tests. The paper then researches into different solutions proposed by comparative law concerning the use of data from genetic tests for insurance purposes. Some solutions explicitly ban the use of genetic tests for insurance purposes (France, Austria, Portugal, Croatia), while others adopt a more liberal approach, allowing for its use (the USA, the UK, Germany). It is concluded that personal data protection does not exclude the possibility using data from genetic tests for insurance purposes, which proves the need for a common EU approach to the issue.

Keywords: $\quad$ insurance, genetic screening, personal data, comparative law, the European Union, General Data Protection Regulation

\section{(c) (i) \&}

This work is licensed under a Creative Commons

Attribution-NonCommercial 4.0 International License.

* Maja Bukovac Puvača, PhD, Full Professor, University of Rijeka, Faculty of Law, Hahlić 6, 51000 Rijeka, Republic of Croatia. E-mail address: bukovac@pravri.hr. ORCID: https://orcid.org/0000-0003-3266-2108.

** Loris Belanić, PhD, Associate Professor, University of Rijeka, Faculty of Law, Hahlić 6, 51000 Rijeka, Republic of Croatia. E-mail address: lorisb@pravri.hr. ORCID: https://orcid.org/0000-0002-8275-488X. 